\title{
The Influence of Total Quality Management, Market Orientation and E-Marketing on Hotel Performance
}

\author{
Ibrahim Bazazo $^{1}$, Iman Alansari ${ }^{2}$, Haya Alquraan ${ }^{1}$, Yasmeen Alzgaybh ${ }^{1} \&$ Ra'ed Masa'deh $^{3}$ \\ ${ }^{1}$ Department of Tourism Management, Faculty of Tourism and Hospitality, The University of Jordan, Aqaba, Jordan \\ 2 Taibah University, Department of Computer Science, Medina, Saudi Arabia \\ ${ }^{3}$ Management Information Systems Department, School of Business, The University of Jordan, Amman, Jordan \\ Correspondence: Ibrahim Bazazo, Department of Tourism Management, Faculty of Tourism and Hospitality, The \\ University of Jordan, Aqaba, Jordan. Tel: 962-3-209-0450. E-mail: i.bazazo@ju.edu.jo
}

Received: June 15, 2017

doi:10.5430/ijba.v8n4p79
Accepted: June 22, 2017

Online Published: June 27, 2017

\begin{abstract}
The purpose of this study is to examine the associations among total quality management, market orientation, e-marketing, and hotel performance. A survey instrument was used to examine the relationships in the proposed model. The collected primary data $(\mathrm{n}=191)$ from different employees in Aqaba hotels located in Jordan is conducted to test the relationship between exogenous and endogenous construct expressed in the proposed structural model. By employing SEM analysis, the findings revealed that e-marketing and market orientation have significant impact on hotel performance, whereas total quality management has not significant impact on it. However, the total quality management found to impact market orientation. In addition, the research will contribute a better understanding of hotel performance antecedents' towards hotels in Aqaba city.
\end{abstract}

Keywords: total quality management, market orientation, e-marketing, hotel performance, Aqaba, Jordan, SEM (Structural Equation Modeling)

\section{Introduction}

With the increasing global tourist traffic and increase the willingness of individuals to move from one place to another, or move from the atmosphere of the city or the work environment to the coast or the mountains, any tourist moves from one place to another for more than 24 hours, it certainly needs to be far from the shelter his home, the place where he provides the service, of course, is the hotel. Hotels have become in the present day social and cultural centers that meet society's needs and desires and became a presence. Indeed, the world has seen in recent years, sophisticated and interesting large hotel industry has the hotel industry began to play an active role in the tourism development of the country concerned, and the hotel industry has become an essential pillar in the tourism industry (Wang et al. 2012). The hotel industry as well as its importance in terms of tourism and offer state-of-service as an important source of foreign exchange and the industry task in the elimination of unemployment at the same time they are of high-profit industries, especially that the state encourages those industries tax and customs exemptions on most operating requirements and the needs of the hotel. The modern trend of the hotel industry is the tourism industry itself. If you take some hotels organize tours of the city to another and from one country to another and in agreement with the global airlines or other companies to own one and that is the accommodation in the same hotel or in the same chain hotels. Hence, the importance of the role of hotels in the national economy as it considered tourism organizations independent industry itself. So the hotel industry requires in these days and care for large and support science and technology and increase the quality of services and performance of care so that they can effectively perform its role in the national economy and development and to meet the wishes of the customer service.

Tourism is an increasingly globalized sector in which inter-destination competition is becoming greater and greater. This phenomenon is caused, amongst other things, by the fact that tourism enterprises, among which are hotels, now find themselves in a better position to compete in international destinations, which in turn results in increased international competition, not only between destinations but also between hotel establishments. On the other hand, tourists are increasingly demanding and do not only focus on the price. The hotel enterprise's competitiveness must focus on improving performance through better service quality and the search for differentiation greater 
competitiveness has made quality become a key factor for hospitality hotels. Total Quality Management (TQM) is recognized widely management philosophy, and became a major theme as organizations seeking competitive advantage in the market (Sureshchandar et al. 2001). The focus of total quality management in the process of continuous improvement within the institutions to provide excellent value to customers and meet customer needs. Meeting customer needs involves hotel operations that focus on understanding and participation, and responsiveness to customers through the marketing concept. It is said that the adoption and implementation of the marketing concept aimed at market orientation Hotels (Lamb et al., 2005). Therefore, the overall quality and market-oriented management can be a high value of the company's strategy and provide a competitive advantage to respond to the competitive business environment.

Total Quality Management (TQM) and market orientation (MO) is to focus on customer needs and satisfaction. It was found that the hotels market-oriented to be successful in maintaining a strong competitive positions with the passage of time; adopt TQM in obtaining a competitive advantage over hotels that do not support total quality management, but 1/3 of the hotels that do not support the TQM still have a doubt and lack of full knowledge that the main factor was the lack of understanding of the topics of marketing and its importance in maintaining the continuity of the hotel and maintain a competitive advantage and market share at the hotel managers and administrators in hotels. As a result, the process of globalization that has occurred over the past few decades has become a competition in the hotel sector. For long-term survival in an increasingly competitive environment depends on the hotels with a capacity to satisfy customers' demands efficiently and effectively. Adoption of market orientation can help in the design of the hotel, and a variety of services that are perceived by customers as the core of high quality, and this helps to make a profit, and build a competitive advantage to the high hotel (Kohli \& Jaworski, 1990).

Learning and accumulation of knowledge through the collection of information on an ongoing basis on customers, competitors use the information to create value for customers, creating a competitive advantage above. Compared with other commercial services sectors such as banking, insurance, or retail distribution, and the hotel industry has been slow to adopt marketing discipline (Calantone \& Mazanec, 1991). Thus, it is believed that the investigation of market orientation in the hotel sector can enhance the overall understanding of the concept of market orientation in the context of service. Narver \& Slater (1990) hypothesized that market orientation is one of the dimensions of constructive it consists of three components: customer orientation, competitor career orientation and coordination. On the other hand, Ruekert (1992) definition of the level of market orientation in the business unit as the degree to which the business unit: help in getting the information from customers; develop a strategy that will meet the needs of customers, and apply this strategy by being responsive to customer needs and desires.

Also, the growing presence of the Internet in everyday life in the Internet has resulted in a fundamental means of media in communication and marketing. To get a competitive advantage in the tourism market demands, it is important at the present time for the company hotels have their own website, and promote their products through social networks and mobile applications, and use e-mail as a communication channel with business partners and customers its partners, and the application of all available information and communications technology (ICT). It needs to provide information about potential customers in one place at any time of day, from anywhere in the world. It can be possible by using innovative ways to communicate and adapt business operations to demand the modern tourist market requirements. This imposes on the innovation of the practice and application of new technologies in business processes. Therefore, there is a need to increase awareness about the need for the application of information and communication technology in the hotel sector (Lončarić \& Radetić, 2015). Indeed, several researchers consider the information systems and in particular the information technology (IT) and its flexibility as an enabler to achieve the desired competitive advantages, and as a crucial support to operational and strategic business decisions (Al Azmi et al., 2012; Alenezi et al., 2015; Alkalha et al., 2012; Almajali \& Tarhini, 2016; Altamony et al., 2012; Kateb et al., 2015; Maqableh \& Karajeh, 2014a, 2014b; Masa'deh, 2012, 2013a, 2013b; Masa'deh et al., 2016; Obeidat et al., 2013; Shannak et al., 2010, 2012a, 2012b; Tarhini et al., 2016; Vratskikh et al., 2016); thus further research is required to examine the role of such IT applications in enhancing the managerial decisions. In addition, scholars (e.g. Masa'deh et al. 2008; Hunaiti et al., 2009; Masa'deh \& Kuk, 2009; Alshurideh et al., 2012; Hajir et al., 2015; Kannan \& Gharibeh, 2013; Masa'deh \& Shannak, 2012; Masa'deh et al. 2013; Masa'deh et al. 2015a, 2015b, 2015c; Masa'deh et al. 2017; Obeidat et al., 2012, 2016; Shannak \& Alkour, 2012; Tarhini et al., 2015a, 2015b) emphasize the need for large firms to integrate their IT systems with their KM strategies and processes in order to survive in their highly competitive business environments, which in turn could accelerate the managerial decisions as well.

There are many factors which are essential requirements for the use of e-marketing in hotels. For example, indicate the existence of a clear strategy on the hotel level, the existence of the marketing function in the hotel, and control of the marketing function in the development, implementation and monitoring of the results of e-marketing, a data base 
and building relationships with customers (Peštek \& Čičić, 2010). When it comes to the implementation of e-marketing in the field of tourism in hotels can say that the acceptance of e-marketing is determined by many factors, for example, the owner skills, and resources available for the hotel, and organizational culture of the hotel, the cost of adoption of e-marketing, and the size of the hotel, and ease of use, and compatibility, competitive pressures, the influence of the government, and market trends, and the infrastructure of the hotel, the cultural and the trend towards e-marketing by the clients of the hotel the letters (El-Gohary, 2012). Also, there are many obstacles to the adoption of e-marketing. Examination (Dlodlo \& Dhurup) related that contribute to the failure to adopt e-marketing practices by small and medium-sized companies, and found that they include incompatibility technology with target markets, and lack of knowledge, lack of satisfaction of the stakeholders barriers, and confusion of technology and cognition technology (Dlodlo \& Dhurup, 2010). In their research, which was conducted in hotels they found that organizational characteristics are the most important factors that determine the adoption and use of information and communications technology, despite the fact that "environmental context" hotels are considered the internet has influence on the hotel environment.

The purpose of the current study is to know the effect of quality management, e-marketing and market-oriented on the performance of the hotel, and is there a relationship between them and the success of the hotel as to increase production and increase its share and market competitive advantage. The aim of the study is to identify the overall quality standards in the performance of the hotel, measure the importance of e-marketing in the performance of the hotel, indicate the role of market orientation in activating the system performance of the hotel, find a correlation between market orientation and e-marketing for alternative mechanisms in tourism services, know the relationship between total quality management and market orientation and e-marketing on the performance of the hotel, to identify the relationship between total quality management and performance of the hotel, to identify the relationship between market orientation and performance of hotel, and to identify the relationship between e-marketing and hotel performance.

\section{Hypotheses Development}

\subsection{Total Quality Management and Market Orientation}

Showing that the total quality management encourages competencies adept in knowledge generation and exchange in the market to enhance customer value and satisfaction for the services provided to them, which is a prerequisite for success in the long run hotels (Kerin et al., 2006). Wang \& Wei (2005) showed that market orientation positively affects the fixed market share or strengthens the market in total quality management. The overall quality, core management for the success of the application of the concept of marketing, and is a way to increase the preponderance of Marketing (Santos-Vijande et al., 2009). Tena et al. (2001) found that Total Quality Management linked activities to help the development of distinctive competencies which is a mediating variable in the relationship between TQM and performance. TQM focuses on the internal processes continuous improvement can improve the implementation of the marketing concept (Mohr-Jackson, 1991). TQM implementation appears to play an important mediating role in increasing the strength of the association between market orientation and performance (Mehmet \& Lenny, 2006). Clearly even joining TQM and market orientation together, the empirical findings are mixed and no homogeneous results have been obtained about the existence of their relation. Therefore, by adopting TQM philosophies offer a systematic approach in order to develop a work environment, help to adoption of market orientation, and further promotes hotel performance. The following hypothesis is proposed:

H1: Total Quality Management positively affects Market Orientation.

\subsection{Total Quality Management and Hotel Performance}

Directors design strategies to achieve high performance of hotels, while the total quality management affect positively the performance of the hotel and positively affects the market of the performance of the hotel where he/she directed; the market has the effect between total quality management and performance of the hotel total quality management and market orientation affects positively on the performance of the hotel, where it is necessary to integrate the total quality management with the market orientation of the performance of the hotel because of environmental factors affect the performance of hotels. Wang \& Chen (2011) adopt the Input Processing Output (IPO) concept model to construct all variables of their research model. The study concluded that due to some factors such as the environmental ones, TQM positively affects hotel performance. Market orientation positively affects hotel performance. Market orientation has the mediating effect between TQM and hotel performance (Grandzol \& Gershon, 1998). The researchers believe that hotels that adopt TQM are focused on customer focus, continuous improvement, leadership, and internal and external cooperation, in fulfillment of the staff, learning, and process management. Lazari \& Kanellopoulos (2007) study is based on total quality management structures. Total quality 
management found to be largely not applied because executives have not contended with it or consider it unnecessary in the hotel industry. Through the study, they realized the containment on the competitive performance and satisfaction of stakeholders. Any organization needs to find funding and support. To maximize corporate performance over the long term must build and maintain mutually beneficial relationships with buyers (Narver \& Slater, 1990). Montes et al. (2003) definitions do not fully coincide, all those basic factors that make up the total quality management theoretical framework, without the implementation of the organization on which to base management system it cannot be called total quality management. The adoption of TQM hotel could lead to improved performance of the hotels. Therefore, the current research stated the second hypothesis:

H2: Total Quality Management positively affects Hotel Performance.

\subsection{E-Marketing and Hotel Performance}

According to Coviello et al. (2001), from the list of e-marketing activities on innovative technology and modern, it has been considered as one of the key aspects of marketing practice that involves the use of the Internet and other interactive technologies to create and mediate dialogue between hotels and customers. Wu et al. (2003), showed that inspite of the growing interest in e-marketing, the presence of limited data in the literature arrived in e-marketing in business performance in the hotels. Until recently, research reports have shown the existence of contradictory results on the relationship between marketing and e-business performance in hotels. Brodie et al. (2007) said that Internet resources withstand an impact indirectly on hotel performance-brokered customer orientation. They studied four types of technology-based industries in the United States reported a positive impact of e-business on the density of hotel performance as between business efficiency, sales performance, customer satisfaction, and the development of the relationship between hotels and customers. Recently, it reported that the resources of the Internet hold its indirect impact on the performance of mediated orientation towards customers. Lončarić \& Radetić (2015) stated that information technology has become a key in many areas of life and work whereas the level of implementation of e-marketing in the hotel industry as hotels that have a level of high in the practice of e-marketing best performance questions were aimed at collecting data on business performance. The aim of the study was to determine the technology of information and communication used in hotels where hotels tend to use different techniques to maintain relationships with customers and meet their needs and help employees do their job as the Internet is part of a strategy of marketing the hotel, and also the study aimed to identify the causes that led to inadequate the application of information and communications technology such as lack of financial resources, lack of knowledge about the importance of information and communication technology, and the lack of experts. Through previous studies, this research suggested the following hypothesis:

H3: E-Marketing has a direct positively affects Hotel Performance.

\subsection{Market Orientation and Hotel Performance}

It is important to investigate a relationship between market orientation and performance of hotel. The literature indicated that the market orientation is positive and significantly associated with marketing performance and financial performance of the hotel. Since the market orientation has a positive impact on the marketing and financial performance and the world for the hotel industry in the dome where the advantage achieved through which competitive sustainable and maintain a high degree of market orientation (Sin et al., 2005). (Kohli \& Jaworski 1990) showed mutual case for TQM and market orientation in hotels. Comprehensive continuous monitoring of market forces include quality management through the implementation of regulatory processes, and involve all hotel departments to develop a proper response to the market, all of which lead to reach the desired market. Raju \& Lonial (2002); Sittimalakorn \& Hart (2004) stated that the trend towards market orientation mediates the effect of quality on the competitive edge effect, and competitive edge leads to business performance. Decided to market orientation should include a focus on customers and prospective customers of the hotel (Anwar, 2008). The concentration of competitive, environmental scanning and implementation of the strategy, and the development of new services in the companies are crucial to a better hotel performance. Different hotels depend on different strategies; this study shows that market orientation is more suitable for data collection, including the generation and dissemination of information, common interpretation, organization and responsiveness. The following hypothesis is proposed:

H4: Market Orientation positively affects Hotel Performance.

\section{Research Methodology}

This section provides the methodology applied in the current study. It consists of the research model, operational definitions of the study's independent, mediating and dependent variables; research hypotheses, besides data collection tool and research population and sample. 


\subsection{Research Model}

The elements of this research are established based on preceding literature, either theoretically or empirically. Indeed, this study used variables that are common in hotel management literature. Adapted from (Wang et al. 2012), the current research considers total quality management, market orientation, and hotel performance; which were measured in the research questionnaire through several dimensions. Indeed, TQM used seven dimensions namely customer focus, internal/external cooperation, continuous improvements, leadership, employee fulfillment, learning, and process management. Market orientation was measured by using four dimensions which are information generation, information dissemination, shared interpretation, and organization responsiveness. Also, hotel performance was measured through both customer performance, and financial performance. In addition, e-marketing was adapted from (Lončarić \& Radetić 2015) and measured through nine items. Figure 1 represents a model for the study that shows the relationships among the research variables.

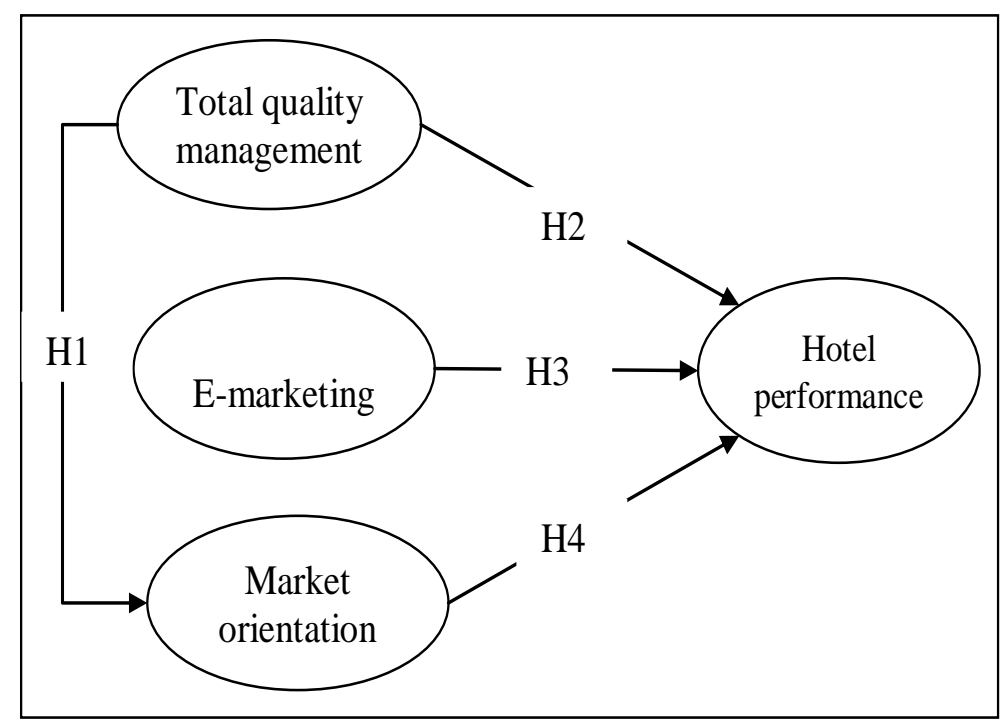

Figure 1. Research Model

\subsection{Population and Sampling}

Empirical data for this study was collected through paper-based survey in Aqaba city in Jordan. Specifically, a survey questionnaire was used to gather data for hypotheses testing from tourists. Before implementing the surveys, the instrument was reviewed by four lecturers who are specialized in the hotel management discipline in order to identify problems with wording, content, and question ambiguity. After some changes were made based on their suggestions, the modified questionnaire was piloted on four employees who are working in hotels located in Aqaba city. Based on the feedback of this pilot study, minor edits were introduced to the survey questions, and the questionnaires were distributed to the participants. As per ethics policies, all potential participants were briefed about the nature of the work and were requested to provide explicit approval. The population of this study consists of all employees working in hotels located in Aqaba, which counts of more than 2384 according to the Jordanian ministry of tourism, and according to Morgan Table data, 331 employees should be reached as the size of statistical sample of this research (Sekaran \& Bougie, 2013). However, the sample size of this study was determined based on the rules of thumb for using SEM within AMOS 21 in order to obtain reliable and valid results. Kline (2010) suggested that a sample of 200 or larger is suitable for a complicated path model. Furthermore, after eliminating the incomplete surveys, our sample size 191 from employees nearly met the recommended guidelines of (Kline 2010), (Krejcie \& Morgan 1970) and (Pallant 2005). The demographic data of the respondents are reported in Table 1. 
Table 1. Description of the respondents' demographic profiles

\begin{tabular}{|c|c|c|c|}
\hline Category & Category & Frequency & Percentage\% \\
\hline \multirow[t]{3}{*}{ Gender } & Males & 142 & 74.3 \\
\hline & Females & 49 & 25.7 \\
\hline & Total & 191 & 100 \\
\hline \multirow[t]{5}{*}{ Age } & From 18 to less than 25 years & 59 & 30.9 \\
\hline & From 25 to less than 35 years & 86 & 45.0 \\
\hline & From 35 to less than 45 years & 33 & 17.3 \\
\hline & More than 45 years & 13 & 6.8 \\
\hline & Total & 191 & 100 \\
\hline \multirow[t]{7}{*}{ Education level } & High school & 25 & 13.1 \\
\hline & Diploma & 43 & 22.5 \\
\hline & Bachelor & 66 & 34.6 \\
\hline & Master & 51 & 26.7 \\
\hline & Doctorate & 4 & 2.1 \\
\hline & Professional degree & 2 & 1.0 \\
\hline & Total & 191 & 100 \\
\hline \multirow{6}{*}{$\begin{array}{l}\text { Classification of } \\
\text { hotels }\end{array}$} & One stars & 11 & 5.8 \\
\hline & Two stars & 24 & 12.6 \\
\hline & Three stars & 36 & 18.8 \\
\hline & Four stars & 31 & 16.2 \\
\hline & Five stars & 89 & 46.6 \\
\hline & Total & 191 & 100 \\
\hline \multirow[t]{5}{*}{ Career level } & Top level management & 18 & 9.4 \\
\hline & Middle level management & 35 & 18.3 \\
\hline & Supervisor & 46 & 24.1 \\
\hline & Back offices & 92 & 48.2 \\
\hline & Total & 191 & 100 \\
\hline
\end{tabular}

As indicated in Table 1, the demographic profile of the respondents for this study showed that they are typically males, most of them 18-35 years old, the majorities hold bachelor and master degrees, $46.6 \%$ of them working in 5 star hotels, and the majorities working in the back offices.

\section{Data Analysis and Results}

In order to explore the associations among total quality management, market orientation, e-marketing, and hotel performance, in which these variables have been measured using 5-points Likert scale that varies between strongly disagree $=1$ and strongly agree $=5$; reliability and validity analyses were conducted, descriptive analysis was used to describe the characteristic of sample and the respondent to the questionnaires besides the independent and dependent variables. Also, SEM analysis was employed to test the research hypotheses. Table 2 shows the measured constructs and the items measuring each construct.

Table 2. Constructs and measurement items

\begin{tabular}{ll}
\hline Construct & Measurement Items \\
\hline Total Quality Management (TQM) & \\
\hline Customer Focus (CF) & CF1: Our activities are centered on satisfying our customers. \\
& CF2: Satisfying our customers, and meeting their expectations, is the most \\
important thing we do.
\end{tabular}


CF3: Senior executives behave in ways that lessen the importance of customers.

Internal/External Cooperation (IC)
IC1: Managers emphasize activities that lead to cooperation between our hotel lands our suppliers.

IC2: Managers, supervisors, and employees from different departments work dependently to achieve their own department's goals.

IC3: In the hotel, teamwork is commonplace - the expected way of doing business.

IC4: Employees do not hesitant to voice their opinions, make suggestions, or inquire about any of the actives of the hotel.

IC5: In the hotel, every one participates in improving our products, services, and processes.

Continuous Improvements (CI) CI1: Employees usually get an opportunity to suggest changes or modifications to existing processes.

CI2: The hotel encourages continual study and improvement of all its products, services and processes.

CI3: The hotel has received recent compliments and recognition for improving its products / services / processes.

Leadership (LS)

LS1: Senior executives share similar beliefs about the future direction of this hotel.

LS2: Activities and investments that have long-term benefits receive support from management.

LS3: Managers and supervisors allow employees to take necessary action on their own.

LS4: Senior executives anticipate change and make plans to accommodate.

Employee Fulfillment (EF) EF1: My work duties and responsibilities contribute to satisfying my need to create quality products/services.

EF2: I like my job because I'm doing what I want to do.

EF3: Employees in the hotel dictated to their jobs.

Learning (LG)

LG1: Managers and supervisors ensure that all employees receive training that helps them understand how and why the hotel does what it does.

LG2: Managers and supervisors participate in specialized training on how to conduct business, whether dealing with employees or external customers.

LG3: Many employees in the hotel possess sufficient knowledge about the basics of our industry.

LG4: Many employees in the hotel understand the basic processes used to create our products/services.

Process Management (PM)
PM1: Preventing defective products /services from occurring is a strong attitude in the hotel.

PM2: The processes used in the hotel include in-process measures of quality.

PM3: The processes for designing new products / service in the hotel ensure quality.

PM4: Explaining the variation in processes is used as an analysis technique in the hotel.

PM5: Senior executives look at the total costs of products and service, including in direct an overhead costs.

PM6: Managers and supervisors understand how to motivate employees and encourage them to perform at their highest levels. 


\begin{tabular}{|c|c|}
\hline http://ijba.sciedupress.com & International Journal of Business Administration \\
\hline \multirow[t]{2}{*}{ Information Generation (IG) } & IG1: We are fast to detect changes in our customers' product preferences. \\
\hline & $\begin{array}{l}\text { IG2: We are fast to detect fundamental shifts in our industry (e.g., } \\
\text { competition, technology). }\end{array}$ \\
\hline \multirow[t]{2}{*}{ Information Dissemination (ID) } & $\begin{array}{l}\text { ID1: When something important happens to major customers, the whole } \\
\text { hotel knows about it shortly. }\end{array}$ \\
\hline & $\begin{array}{l}\text { ID2: When one unit finds out something important about competitors, it is } \\
\text { fast to alert other units. }\end{array}$ \\
\hline \multirow[t]{2}{*}{ Shared Interpretation (SI) } & $\begin{array}{l}\text { SI1: We develop a shared understanding in our hotel of the available market } \\
\text { information. }\end{array}$ \\
\hline & $\begin{array}{l}\text { SI2: We develop a shared understanding in our hotel of the implications of a } \\
\text { marketing activity. }\end{array}$ \\
\hline \multirow[t]{3}{*}{$\begin{array}{l}\text { Organization Responsiveness } \\
\text { (OR) }\end{array}$} & $\begin{array}{l}\text { OR1: It takes us a short time to decide how to respond to our competitor's } \\
\text { price changes. }\end{array}$ \\
\hline & $\begin{array}{l}\text { OR2: We are fast to respond to changes in our customer's product or } \\
\text { service needs. }\end{array}$ \\
\hline & $\begin{array}{l}\text { OR3: If a major competitor launched a campaign to our customers, we } \\
\text { implement a response immediately. }\end{array}$ \\
\hline \multirow[t]{9}{*}{ E-Marketing (EM) } & $\begin{array}{l}\text { EM1: We collect and exchange market information through online dialogue } \\
\text { with customers. }\end{array}$ \\
\hline & $\begin{array}{l}\text { EM2: Our marketing communication involves using technology to } \\
\text { communicate with and among many individuals. }\end{array}$ \\
\hline & $\begin{array}{l}\text { EM3: We communicate electronically with our clients continuously and } \\
\text { interactively. }\end{array}$ \\
\hline & $\begin{array}{l}\text { EM4: When customers buy our products, we believe they expect to interact } \\
\text { through technology. }\end{array}$ \\
\hline & $\begin{array}{l}\text { EM5: Communication with customers is personalized with the use of } \\
\text { interactive technology. }\end{array}$ \\
\hline & EM6: Our marketing activities are intended to create IT-enabled dialogue. \\
\hline & $\begin{array}{l}\text { EM7: Our marketing planning is focused on issues related to managing } \\
\text { IT-enabled relationships between the firm and individuals. }\end{array}$ \\
\hline & $\begin{array}{l}\text { EM8: Our marketing resources (e.g. people, time, money) are invested in } \\
\text { the creation of IT-enabled dialogue. }\end{array}$ \\
\hline & $\begin{array}{l}\text { EM9: In this hotel, marketing activities are carried out by marketing } \\
\text { specialists in collaboration with technology experts. }\end{array}$ \\
\hline \multicolumn{2}{|l|}{ Hotel Performance (HP) } \\
\hline \multirow[t]{4}{*}{ Customer Performance (CP) } & CP1: Our customers are loyal. \\
\hline & CP2: Our customers are satisfied. \\
\hline & CP3: Our products/service bring for customer life time value. \\
\hline & CP4: Our customers are willing to retain. \\
\hline \multirow[t]{4}{*}{ Financial Performance (FP) } & FP1: Our market share is growing. \\
\hline & FP2: Our sales are growing. \\
\hline & FP3: Our selling cost is reducing. \\
\hline & FP4: Our (Return on Investment) is growing. \\
\hline
\end{tabular}

\subsection{Descriptive Analysis}

In order to describe the responses and thus the attitude of the respondents toward each question they were asked in the survey, the mean and the standard deviation were estimated. While the mean shows the central tendency of the data, the standard deviation measures the dispersion which offers an index of the spread or variability in the data (Pallant, 2005; Sekaran \& Bougie, 2013). In other words, a small standard deviation for a set of values reveals that 
these values are clustered closely about the mean or located close to it; a large standard deviation indicates the opposite. The level of each item was determined by the following formula: (highest point in Likert scale - lowest point in Likert scale) / the number of the levels used $=(5-1) / 5=0.80$, where 1-1.80 reflected by "very low", 1.81-2.60 reflected by "low", 2.61-3.40 reflected by "moderate", 3.41-4.20 reflected by "high", and 4.21-5 reflected by "very high". Then the items were being ordered based on their means. Tables 3 and 4 show the results.

Table 3. Overall mean and standard deviation of the study's variables

\begin{tabular}{cllccc}
\hline $\begin{array}{c}\text { Type of } \\
\text { Variable }\end{array}$ & Variables & Mean & Standard Deviation & Level & Order \\
\hline $\begin{array}{c}\text { Independent } \\
\text { Variables }\end{array}$ & Total Quality Management & 3.49 & 0.41 & High & \\
\hline & Customer Focus & 3.81 & 0.57 & Moderate & 4 \\
\hline & Internal/External Cooperation & 3.34 & 0.62 & Moderate & 5 \\
\hline & Continuous Improvements & 3.60 & 0.72 & High & 1 \\
\hline & Leadership & 3.32 & 0.63 & Moderate & 7 \\
\hline & Employee Fulfillment & 3.54 & 0.63 & High & 2 \\
\hline & Learning & 3.34 & 0.72 & Moderate & 5 \\
\hline & Process Management & 3.47 & 0.58 & High & 3 \\
\hline $\begin{array}{c}\text { Mediating } \\
\text { Variable }\end{array}$ & E-Marketing & 3.54 & 0.94 & High & High \\
\hline & Information Generation & 3.68 & 0.76 & High & 2 \\
\hline & Information Dissemination & 3.87 & 0.93 & High & 1 \\
\hline & Shared Interpretation & 3.48 & 1.00 & High & 4 \\
\hline & Organization Responsiveness & 3.69 & 0.89 & High & 3 \\
\hline Dependent & Hotel Performance & 3.74 & 0.82 & High & High \\
\hline
\end{tabular}

As presented in Table 3, data analysis results have shown that market orientation, e-marketing, and total quality management in Aqaba hotels do exist highly and respectively. Also, hotel performance is applied to a greater extent. Table 4 demonstrates the mean, standard deviations, level, and order scores for items to each variable.

Table 4. Mean and standard deviation of the study's variables

\begin{tabular}{lcccc}
\hline Customer Focus & Mean & SD & Level & Order \\
\hline CF1 & 4.39 & 0.76 & Very high & 2 \\
\hline CF2 & 4.41 & 0.78 & Very high & 1 \\
\hline CF3 & 2.63 & 1.41 & Moderate & 3 \\
\hline Internal/External Cooperation & Mean & SD & Level & Order \\
\hline IC1 & 3.24 & 1.20 & Moderate & 3 \\
\hline IC2 & 2.72 & 1.11 & Moderate & 5 \\
\hline IC3 & 3.92 & 0.95 & High & 1 \\
\hline IC4 & 3.02 & 1.19 & Moderate & 4 \\
\hline IC5 & 3.83 & 0.95 & High & 2 \\
\hline Continuous Improvements & Mean & SD & Level & Order \\
\hline
\end{tabular}




\begin{tabular}{|c|c|c|c|c|}
\hline CI1 & 3.18 & 1.20 & Moderate & 3 \\
\hline $\mathrm{CI} 2$ & 4.04 & 0.81 & High & 1 \\
\hline CI3 & 3.59 & 1.05 & High & 2 \\
\hline Leadership & Mean & SD & Level & Order \\
\hline LS1 & 3.68 & 1.00 & High & 2 \\
\hline LS2 & 2.82 & 1.09 & Moderate & 4 \\
\hline LS3 & 2.90 & 1.11 & Moderate & 3 \\
\hline LS4 & 3.90 & 0.93 & High & 1 \\
\hline Employee Fulfillment & Mean & SD & Level & Order \\
\hline EF1 & 2.87 & 1.12 & Moderate & 3 \\
\hline EF2 & 3.86 & 0.88 & High & 2 \\
\hline EF3 & 3.92 & 0.89 & High & 1 \\
\hline Learning & Mean & SD & Level & Order \\
\hline LG1 & 3.74 & 1.04 & High & 1 \\
\hline LG2 & 3.68 & 0.98 & High & 2 \\
\hline LG3 & 2.97 & 1.11 & Moderate & 3 \\
\hline LG4 & 2.97 & 1.22 & Moderate & 3 \\
\hline Process Management & Mean & SD & Level & Order \\
\hline PM1 & 3.64 & 0.98 & High & 2 \\
\hline PM2 & 3.41 & 1.21 & High & 5 \\
\hline PM3 & 3.67 & 1.13 & High & 1 \\
\hline PM4 & 2.96 & 1.10 & Moderate & 6 \\
\hline PM5 & 3.58 & 0.98 & High & 4 \\
\hline PM6 & 3.61 & 1.01 & High & 3 \\
\hline E-Marketing & Mean & SD & Level & Order \\
\hline EM1 & 3.74 & 0.94 & High & 4 \\
\hline EM2 & 3.66 & 1.02 & High & 5 \\
\hline EM3 & 3.88 & 0.98 & High & 1 \\
\hline EM4 & 3.87 & 1.01 & High & 2 \\
\hline EM5 & 3.51 & 1.06 & High & 7 \\
\hline EM6 & 3.46 & 1.08 & High & 8 \\
\hline EM7 & 3.66 & 1.04 & High & 5 \\
\hline EM8 & 3.80 & 1.00 & High & 3 \\
\hline EM9 & 3.62 & 0.98 & High & 6 \\
\hline Information Generation & Mean & SD & Level & Order \\
\hline IG1 & 3.52 & 1.09 & High & 2 \\
\hline IG2 & 3.61 & 1.07 & High & 1 \\
\hline Information Dissemination & Mean & SD & Level & Order \\
\hline ID1 & 3.60 & 1.07 & High & 1 \\
\hline ID2 & 3.59 & 1.11 & High & 2 \\
\hline Shared Interpretation & Mean & SD & Level & Order \\
\hline SI1 & 3.55 & 1.07 & High & 1 \\
\hline SI2 & 3.48 & 1.11 & High & 2 \\
\hline Organization Responsiveness & Mean & SD & Level & Order \\
\hline OR1 & 3.60 & 1.08 & High & 1 \\
\hline
\end{tabular}




\begin{tabular}{lcccc} 
http://ijba.sciedupress.com & International Journal of Business Administration & \multicolumn{2}{c}{ Vol. 8, No. 4, Special issue; 2017 } \\
\hline & & & & \\
\hline OR2 & 3.43 & 1.08 & High & 3 \\
\hline OR3 & 3.51 & 1.12 & High & 2 \\
\hline Customer Performance & Mean & SD & Level & Order \\
\hline CP1 & 3.87 & 1.00 & High & 2 \\
\hline CP2 & 3.86 & 0.99 & High & 3 \\
\hline CP3 & 3.82 & 1.02 & High & 4 \\
\hline CP4 & 3.98 & 0.96 & High & 1 \\
\hline Financial Performance & Mean & SD & Level & Order \\
\hline FP1 & 3.64 & 0.99 & High & 3 \\
\hline FP2 & 3.75 & 1.03 & High & 1 \\
\hline FP3 & 3.37 & 1.23 & Moderate & 4 \\
\hline FP4 & 3.70 & 1.09 & High & 2
\end{tabular}

\subsection{Measurement Model}

Confirmatory factor analysis (CFA) was conducted to check the properties of the instrument items. Indeed, the measurement model indicates how latent variables or hypothetical constructs are assessed in terms of observed variables; and embodies the validity and reliability of the observed variables responses for the latent variables (Bagozzi \& Yi, 1988; Hair et al., 2006). Table 5 shows different types of goodness of fit indices in assessing this study initial specified model. Because the initial CFA model did not provide an acceptable fit, thirteen items (CF3, IC2, IC3, IC5, CI3, LS2, EF1, LG3, LG4, PM1, PM2, PM4, and FP3) were eliminated to obtain a better fitting measurement model. The results of the revised CFA indicated that the chi-square $\left(\mathrm{x}^{2}\right)$ value of the model was 1296.344, with 688 degrees of freedom ( $<$ 0.05), which implies that the measurement did fit the data well. The other model fit indices used for this study were the $\mathrm{x}^{2} / \mathrm{df}(1296.344 / 688=1.884$; threshold less 3 for a serious viewpoint or less 5 for acceptable criteria), the Incremental Fit Index (IFI) of 0.89, Tucker- Lewis Index (TLI) of 0.87, Comparative Fit Index (CFI) of 0.89, the Goodness-of-Fit Index (GFI) of 0.90, the Adjusted Goodness-of-Fit Index (AGFI) of 0.91, the Normed Fit Index (NFI) of 0.92, the Root Mean Square Error of Approximation (RMSEA) of 0.068 , and the Standardized Root Mean Square Residual (SRMR) of 0.056. Based on these fit indices, the measurement model appeared to fit the sample data well (Hair et al., 2010).

Table 5. Measurement model fit indices

\begin{tabular}{lccccccccc}
\hline Model & $\mathbf{x}^{\mathbf{2}}$ & $\mathbf{d f}$ & $\mathbf{x}^{2} / \mathbf{d f}$ & $\mathbf{I F I}$ & $\mathbf{T L I}$ & $\mathbf{C F I}$ & $\mathbf{G F I}$ & AGFI & RMSEA \\
\hline $\begin{array}{l}\text { Initial } \\
\text { Model }\end{array}$ & 2884.79 & 1286 & 2.243 & 0.77 & 0.74 & 0.77 & 0.79 & 0.80 & 0.081 \\
\hline $\begin{array}{l}\text { Final } \\
\text { Model }\end{array}$ & 1296.34 & 688 & 1.884 & 0.89 & 0.87 & 0.89 & 0.90 & 0.91 & 0.068 \\
\hline
\end{tabular}

Table 6 shows the factor loadings, Cronbach alpha, composite reliability, and Average Variance Extracted (AVE) for the variables. All of the indicators of the factor loadings exceeded 0.50, thus constitute evidence of convergent validity (Bagozzi \& Yi, 1988; Creswell, 2009). Indeed, while the measurement reached convergent validity at the item level because all of the factor loadings went above 0.50 , all of the composite reliability values exceeded 0.60 , demonstrating a high level of internal consistency for the latent variables. In addition, since each value of AVE exceeded 0.50 (Bagozzi \& Yi, 1988; Hair et al., 2006), the convergent validity was proved. 
Table 6. Properties of the final measurement model

\begin{tabular}{|c|c|c|c|c|c|c|c|}
\hline $\begin{array}{l}\text { Constructs and } \\
\text { Indicators }\end{array}$ & $\begin{array}{c}\text { Factor } \\
\text { Loadings }\end{array}$ & $\begin{array}{l}\text { Std. } \\
\text { Error }\end{array}$ & $\begin{array}{c}\text { Square } \\
\text { Multiple } \\
\text { Correlation }\end{array}$ & $\begin{array}{c}\text { Error } \\
\text { Variance }\end{array}$ & $\begin{array}{c}\text { Cronbach } \\
\text { Alpha }\end{array}$ & $\begin{array}{l}\text { Composite } \\
\text { Reliability* }\end{array}$ & $\underset{* *}{\mathbf{A V E}}$ \\
\hline Customer Focus & & & & & 0.845 & 0.90 & 0.80 \\
\hline CF1 & 0.864 & $* * *$ & 0.747 & 0.148 & & & \\
\hline CF2 & 0.863 & 0.111 & 0.745 & 0.155 & & & \\
\hline $\begin{array}{l}\text { Internal/Extern } \\
\text { al Cooperation }\end{array}$ & & & & & 0.771 & 0.87 & 0.77 \\
\hline IC1 & 0.589 & $* * *$ & 0.945 & 0.116 & & & \\
\hline IC4 & 0.678 & 0.163 & 0.766 & 0.114 & & & \\
\hline $\begin{array}{l}\text { Continuous } \\
\text { Improvements }\end{array}$ & & & & & 0.797 & 0.77 & 0.62 \\
\hline CI1 & 0.515 & $* * *$ & 0.265 & 0.151 & & & \\
\hline CI2 & 0.505 & 0.084 & 0.133 & 0.163 & & & \\
\hline Leadership & & & & & 0.724 & 0.89 & 0.73 \\
\hline LS1 & 0.741 & $* * *$ & 0.548 & 0.175 & & & \\
\hline LS3 & 0.505 & 0.124 & 0.133 & 0.114 & & & \\
\hline LS4 & 0.656 & 0.111 & 0.431 & 0.166 & & & \\
\hline $\begin{array}{l}\text { Employee } \\
\text { Fulfillment }\end{array}$ & & & & & 0.717 & 0.87 & 0.78 \\
\hline EF2 & 0.720 & $* * *$ & 0.518 & 0.155 & & & \\
\hline EF3 & 0.776 & 0.133 & 0.602 & 0.157 & & & \\
\hline Learning & & & & & 0.778 & 0.86 & 0.76 \\
\hline LG1 & 0.880 & $* * *$ & 0.480 & 0.159 & & & \\
\hline LG2 & 0.586 & 0.081 & 0.343 & 0.177 & & & \\
\hline $\begin{array}{l}\text { Process } \\
\text { Management }\end{array}$ & & & & & 0.741 & 0.90 & 0.74 \\
\hline PM3 & 0.692 & $* * *$ & 0.480 & 0.179 & & & \\
\hline PM5 & 0.672 & 0.098 & 0.452 & 0.167 & & & \\
\hline PM6 & 0.754 & 0.103 & 0.568 & 0.157 & & & \\
\hline $\begin{array}{l}\text { Information } \\
\text { Generation }\end{array}$ & & & & & 0.849 & 0.91 & 0.84 \\
\hline IG1 & 0.852 & $* * *$ & 0.727 & 0.134 & & & \\
\hline IG2 & 0.869 & 0.073 & 0.756 & 0.138 & & & \\
\hline $\begin{array}{l}\text { Information } \\
\text { Dissemination }\end{array}$ & & & & & 0.861 & 0.91 & 0.84 \\
\hline ID1 & 0.908 & $* * *$ & 0.825 & 0.140 & & & \\
\hline ID2 & 0.833 & 0.066 & 0.694 & 0.145 & & & \\
\hline $\begin{array}{l}\text { Shared } \\
\text { Interpretation }\end{array}$ & & & & & 0.854 & 0.90 & 0.81 \\
\hline SI1 & 0.889 & $* * *$ & 0.791 & 0.164 & & & \\
\hline SI2 & 0.838 & 0.083 & 0.702 & 0.166 & & & \\
\hline $\begin{array}{l}\text { Organization } \\
\text { Responsiveness }\end{array}$ & & & & & 0.896 & 0.93 & 0.82 \\
\hline OR1 & 0.853 & $* * *$ & 0.728 & 0.142 & & & \\
\hline OR2 & 0.825 & 0.067 & 0.680 & 0.141 & & & \\
\hline
\end{tabular}




\begin{tabular}{|c|c|c|c|c|c|c|c|}
\hline OR3 & 0.815 & 0.066 & 0.664 & 0.142 & & & \\
\hline E-Marketing & & & & & 0.958 & 0.97 & 0.83 \\
\hline EM1 & 0.809 & $* * *$ & 0.655 & 0.146 & & & \\
\hline EM2 & 0.840 & 0.073 & 0.705 & 0.138 & & & \\
\hline EM3 & 0.887 & 0.071 & 0.786 & 0.142 & & & \\
\hline EM4 & 0.838 & 0.076 & 0.702 & 0.132 & & & \\
\hline EM5 & 0.875 & 0.072 & 0.765 & 0.140 & & & \\
\hline EM6 & 0.849 & 0.076 & 0.720 & 0.138 & & & \\
\hline EM7 & 0.847 & 0.074 & 0.718 & 0.134 & & & \\
\hline EM8 & 0.853 & 0.074 & 0.727 & 0.137 & & & \\
\hline EM9 & 0.829 & 0.077 & 0.687 & 0.144 & & & \\
\hline $\begin{array}{l}\text { Customer } \\
\text { Performance }\end{array}$ & & & & & 0.925 & 0.95 & 0.80 \\
\hline CP1 & 0.843 & $* * *$ & 0.711 & 0.135 & & & \\
\hline CP2 & 0.840 & 0.068 & 0.706 & 0.135 & & & \\
\hline CP3 & 0.892 & 0.067 & 0.796 & 0.129 & & & \\
\hline CP4 & 0.901 & 0.063 & 0.812 & 0.125 & & & \\
\hline $\begin{array}{l}\text { Financial } \\
\text { Performance }\end{array}$ & & & & & 0.883 & 0.93 & 0.83 \\
\hline FP1 & 0.906 & $* * *$ & 0.821 & 0.131 & & & \\
\hline FP2 & 0.855 & 0.060 & 0.731 & 0.139 & & & \\
\hline FP4 & 0.782 & 0.069 & 0.611 & 0.155 & & & \\
\hline
\end{tabular}

* Employing Fronell \& Larcker's (1981) formula, the composite reliability calculation is expressed by the following equation:

Composite Reliability $=(\Sigma \mathrm{L} i)^{2} /\left((\Sigma L i)^{2}+\Sigma \operatorname{Var}(\mathrm{E} i)\right)$

where $\mathrm{Li}$ is the standardized factor loadings for each indicator, and Var (Ei) is the error variance associated with the individual indicator variables.

** The formula for the variance extracted is:

Average Variance Extracted $=\Sigma \mathrm{Li}^{2} /\left(\Sigma \mathrm{Li}^{2}+\Sigma \mathrm{Var}(\mathrm{E} i)\right)$

where $\mathrm{Li}$ is the standardized factor loadings for each indicator, and Var (Ei) is the error variance associated with the individual indicator variables.

\subsection{Structural Model}

The SEM analysis revealed that the total quality management directly, positively, and significantly affected market orientation $(\beta=0.462, \mathrm{t}=4.675, \mathrm{p}=0.000)$; thus, $\mathrm{H} 1$ was accepted. Also, e-marketing and market orientation found to be directly and positively impacted hotel performance; consequently, $\mathrm{H} 3$ and $\mathrm{H} 4$ were accepted (see Table 7). However, $\mathrm{H} 2$ was rejected as $(\beta=0.091, \mathrm{t}=1.300, \mathrm{p}=0.193)$; that total quality management did not impact hotel performance. Furthermore, the coefficient of determination $\left(\mathrm{R}^{2}\right)$ for the research endogenous variables for market orientation, and hotel performance were 0.10 , and 0.55 respectively, which indicates that the model does moderately account for the variation of the proposed model. 
Table 7. Summary of proposed results for the theoretical model

\begin{tabular}{lcccc}
\hline Research Proposed Paths & \multicolumn{1}{l}{$\begin{array}{l}\text { Coefficient } \\
\text { Value }\end{array}$} & t-value & p-value & $\begin{array}{l}\text { Empirical } \\
\text { Evidence }\end{array}$ \\
\hline $\mathrm{H} 1: \mathrm{TQM} \rightarrow \mathrm{MO}$ & 0.462 & 4.675 & 0.000 & Supported \\
\hline $\mathrm{H} 2: \mathrm{TQM} \rightarrow \mathrm{HP}$ & 0.091 & 1.300 & 0.193 & Not supported \\
\hline $\mathrm{H} 3: \mathrm{EM} \rightarrow \mathrm{HP}$ & 0.396 & 10.553 & 0.000 & Supported \\
\hline $\mathrm{H} 4: \mathrm{MO} \rightarrow \mathrm{HP}$ & 0.525 & 10.743 & 0.000 & Supported \\
\hline
\end{tabular}

TQM: Total Quality Management; MO: Market Orientation; EM: E-Marketing; and HP: Hotel Performance.

\section{Discussion and Conclusions}

This study shows that TQM and market orientation positively affects hotel performance. The hotel should consider TQM or market orientation as a facilitating management tool for improving organizational performance. These results are consistent with those obtained by Claver-Cortés et al. (2008), Langer (1997), and Sin et al. (2005) in hotel industry studies. These may be that hotels implementing TQM or market orientation, which strengthen service, teamwork, and reward systems, and help in modifying business operating speed of responsive to changes in internal and external customer needs (Youssef et al., 1996), thus reducing uncertainty in business management (Van Zyl \& Mathur-Helm, 2007) as to get more improvements and development in hotel performance. Literature review revealed a lack of academic research on the links between TOM and market orientation in the hotel most important for hotel TQM practice. Hoteliers more effectively reinforce these elements in ways such as supplying customized products or focus importance of interdepartmental or external (that is, customers or suppliers) connectedness via networks or through information or communication technology systems.

Market orientation enhances hotel performance. Hoteliers are aware that changes in consumer perception and competitor activities are important for hotels. Hoteliers must also continuously educate and train employees to detect and understand such changes. Furthermore, sharing customer and competitor information within the hotel fulfills customer needs and with new solutions. TQM identifiably affects market orientation. Market orientation has a mediating effect on the relationship between TQM and hotel performance, showing that TQM offers of tools that organization can transform to achieve a market orientation (Yam et al., 2005). Market orientation helps in the design of the hotel and offers a service mix that customers perceive as superior quality in turn enhancing hotel performance. Hotels request close co-ordination between their marketing and departments, and do not only use TQM strategies. But also strengthen marketing strategies to meet and satisfy customer needs in hotel management systems the external environment is constantly changing. Adopting TOM and market orientation as a business strategy is important especially as external environmental factor.

Factors challenge the ability of hotels to understand competitor actives, strive to improve products, services and processes, speed improve responses to competitor actions and follow up the most profitable customers using new technologies such as email, websites or online communities. Consequently, hoteliers adopt TOM and market. Orientation as a save for rainy days method, or as a breadth of resource and more flexible forms to meet changing market needs. Total quality management provides a systematic comprehensive for developing a work environment to build an organization engaged in market orientation behavior, and creating a market orientation atmosphere and environment (Yam et al., 2005). Marketing helps in strategic planning (Piercy, 1998) which leads to improve hotel performance. The analytical results also indicate that the value criterion hotels provide for customers also required. Close coordination between the marketing and quality departments as (Lai, 2003) suggested, which helps promote customer satisfaction and financial performance (Yam et al., 2005). The hotel integrates TQM with market orientation is essential for hotel performance that's to say, the hotel shall call for close coordination ordination between marketing and quality departments.

Total quality management does not affect the performance of the hotel so that these hotels do not implement total quality management because it did not focus on activities that satisfy customers and emphasis on teamwork between departments on these hotels as should be allowed for all to participate in the improvement of products and services, and work to train workers, and to allow workers to take actions of his own even though it did not correspond with another study where total quality management affect positively on the performance of the hotel TQM positively affects hotel performance through improvements in customer focus, internal/external cooperation, leadership, continuous improvement, process management, employee training, empowerment, and rewards. Hoteliers are the 
ones who determine the areas of total quality management in which they invest, and the areas requiring improvements. However, the degree of implementation of the basic elements of TQM influences business performance (Powell, 1995). In this study, elements of TQM such as customer focus (factor loading $=0.75$ ) and internal/external cooperation (factor loading $=0.72$ ) very important for hotel TQM practice. Hoteliers more effectively reinforce these elements in ways such as supplying customized products or services or focus the importance of interdepartmental or external connectedness via networks or through information or communication technology systems. The researches of e-marketing in the hotel industry in Aqaba confirm the assumption that Aqaba hotels have accepted and implemented e-marketing in their businesses. The researches results show that most of the hotel companies surveyed achieved a high level of e-marketing. In their daily operations, the hotel companies use a range of different ICT in communication in the hotel. By creating online dialogue using interactive technology with customers electronically and communicate with clients consistently and interactively, and focused planning and marketing, we have focused on several issues related to the management of information technology to enable relations between the company and individuals. Also, our resources are invested marketing (such as people, time, and money) to create a dialogue on information technology, and implementation of marketing activities by marketing specialists in cooperation with technology experts.

In general, there is a positive attitude towards the use of ICT and the Internet in the hotel business. The respondents are aware of the importance of ICT for success in the highly competitive market. This finding is similar to that in (Lončarić \& Radetić 2015) study that has proved, by conducting research of e-marketing in the hotel industry of Istria County, the research results show that most of the hotel companies surveyed achieved a medium or high level of e-marketing. In their daily operations, the hotel companies use a range of different ICT in communication in the hotel or with the market. Almost all companies use the Internet, Wi-Fi, digital satellite, and TV. The companies that apply e-marketing achieved better hotel performance. That is consistent with previous research (Brodie et al. 2007); (Shuai \& Wu, 2011) despite the constraints that impede the use of ICT and e-marketing in the hotel business; it is evident that using ICT and e-marketing is a necessity. Hotels need to improve the quality of their websites and update content continually, use mobile applications and online booking to a greater extent, use e-mail marketing, foster a personalized relationship and adjust supply to customer requirements, apply social networks, and yes the implementation of e-marketing practice in the hotel industry deserve further attention.

In our study we show that market orientation helps in generating information about changes in the product for our customers and preferences of rapid detection of fundamental shifts in our industry (for example, competition, and technology). The findings indicated that market orientation constitutes a significant determinant of hotel performance. By being market oriented, hotel performance will not only increase their "customer focus and become more customer-oriented" but they will need to gather information about their competitors and respond to their actions while they will try to coordinate and communicate all of their resources within their hotel units. Attracting customers is considerably more difficult and costly than retaining them, particularly during difficult economic conditions, and travel services that are consistently market oriented should be in a better position to maintain their profitability. In sum, if hotels firms wish to increase their performance, they need to adopt first a certain degree of market orientation. The study shows that market orientation constitutes a necessary element for hotels performance, the impact positively on the performance of the hotel that's compatible with the study (Tsiaotso \& Flahibl, 2011) and constitutes the first attempt of this study to investigate the relationship of relations between market orientation, e-marketing, and performance. The results confirm that the market determines the performance of the service orientation. However, this is a double mechanism, directly or indirectly effect mediated by marketing resources such as e-marketing list. This paper integrates points of view of e-marketing and market-oriented in order to clarify the mechanisms by which the performance effects of marketing orientation. This research leaves from previous attempts that have achieved either a direct effect of market orientation on performance or the direct impact of e-marketing performance, suggests that the market orientation of both a direct impact on the performance. Some studies strongly advocate that firms adopt a market orientation to achieve competitive advantage and market orientation may represent an important capability that can transform firm assets into superior performance (Zhou et al., 2005). Therefore, building market-orientated environment will strengthen competitive advantages of enterprise (Barney, 1991). Finally, the hotels that take consideration of quality management, market orientation and e-marketing will lead to improving the performance of the hotel and increase profits and market share.

This study suffers from a number or shortcomings that should be taken into consideration, and perhaps be addressed in future research, as this research aims to hotel industry with distinctive differences in degrees of classification and the degree of turbulence in the market, and the intensity of competition. Questionnaire in this study comprised 54 items that were answered by hotel employees. It was used ways to spend on the road of common variation, including 
the anonymity of the defendant, and that means not to be identified because the terms of the scale, and through the questionnaire show that quality management has been applied loosely in Aqaba hotels so the hotels should seek in the future to achieve quality management by focusing on customer satisfaction and meet their needs; hotel managers should cooperate with the staff to express their views and make suggestions and seek collective action inside the hotel; hotel managers should invest in long-term activities and the ability to keep pace with changes and good planning to perform the services that the administration allows employees to make decisions on their own; hotels should be taking overall quality standards in its services, such as: ISO, and that the services and products offered in designer hotels are well on the basis of quality standards; managers at hotels should be given training programs to improve the level of performance of staff; management should speed capacity in responding to changes available to competitors in the market in the shortest possible time; and the administration must increase the advertising campaigns that help marketing of the hotel and increase its market share.

\section{References}

Abbasi, M. S., Elyas, T., \& Shah, F. (2015). Impact of individualism and collectivism over the individual's technology acceptance behaviour: A multi-group analysis between Pakistan and Turkey. Journal of Enterprise Information Management, 28(6), 747-768. https://doi.org/10.1108/JEIM-12-2014-0124

Al Azmi, N., Al-Lozi, M., Al-Zu'bi, Z., Dahiyat, S., \& Masa'deh, R. (2012). Patients Attitudes toward Service Quality and its Impact on their Satisfaction in Physical Therapy in KSA Hospitals. European Journal of Social Sciences, 34(2), 300-314.

Al-Badi, A., Tarhini, A., \& Al-Kaaf, W. (2017). Financial Incentives for Adopting Cloud Computing in Higher Educational Institutions. Asian Social Science, 13(4), 162-174. https://doi.org/10.5539/ass.v13n4p162

Al-Badi, A., Tarhini, A., \& Al-Sawaei, S. (2017). Utilizing Social Media to Encourage Domestic Tourism in Oman. International Journal of Business and Management, 12(4), 84-94. https://doi.org/10.5539/ijbm.v12n4p84

Al-Badi, A. H., \& Al-Qayoudhi, W. S. (2014). Adoption of social networks in business: Study of users and potential users in Oman. The International Business \& Economics Research Journal (Online), 13(2), 401-415.

Al-Dmour, H., Al-Madani, S., Alansari, I., \& Al-Dmour, R. (2016). Factors Affecting the Effectiveness of Cause-Related Marketing Campaign: Moderating Effect of Sponsor-Cause Congruence. International Journal of Marketing Studies, 8(5), 114-127. https://doi.org/10.5539/ijms.v8n5p114

Al-Dmour, R., \& Obeidat, B. (2015). Strategic IT-Business Alignment as Managers' Explorative and Ecploitative Strategies. European Scientific Journal, 11(7), 437-457.

Alenezi, H., Masa'deh, R., Alalwan, A., \& Al-Qirim, N. (2017). Factors Affecting e-Government Adoption in Kuwait: A Qualitative study. Electronic Journal of e-Government, 15(2), 84-102.

Alenezi, H., Tarhini, A., \& Masa'deh, R. (2015). Investigating the Strategic Relationship between Information Quality and E-Government Benefits: A Literature Review. International Review of Social Sciences and Humanities, 9(1), 33-50.

Alkalha, Z., Al-Zu'bi, Z., Al-Dmour, H., \& Alshurideh, M. (2012). Investigating the Effects of Human Resource Policies on Organizational Performance: An Empirical Study on Commercial Banks Operating in Jordan. European Journal of Economics, Finance and Administrative Sciences, 51, 44-64.

Allam, M., \& Elyas, T. (2016). Perceptions of Using Social Media as an ELT Tool among EFL Teachers in the Saudi Context. English Language Teaching, 9(7), 1-9. https://doi.org/10.5539/elt.v9n7p1

Almajali, D., \& Tarhini, A. (2016). Antecedents of ERP Systems Implementation Success: A Study on Jordanian Healthcare Sector. Journal of Enterprise Information Management, 29(4), 549-565.

Al-Mukhaini, E. M., Al-Qayoudhi, W. S., \& Al-Badi, A. H. (2014). Adoption of social networking in education: A study of the use of social networks by higher education students in Oman. Journal of International Education Research, 10(2), 143-155. https://doi.org/10.19030/jier.v10i2.8516

Al-Qirim, M., Rouibah, K., Serhani, M. A., Yammahi, A. R., \& Yammahi, M. A. (2017). Towards a Personality Understanding of Information Technology Students and their IT Learning in UAE University. Education and Information Technologies, 1-12. https://doi.org/10.1007/s10639-017-9578-1

Al-Qirim, N., Rouibah, K., Serhani, M. A., Yammahi, A. R., \& Yammahi, M. A. (2017). Learning Orientations of IT Higher Education Students in UAE University. Education and Information Technologies, 1-14. https://doi.org/10.1007/s10639-017-9589-y 
Al-Qirim N., Tarhini, A., Rouibah, K. (2017). Determinants of Big Data Adoption and Success. In International Conference on Communications and Future Internet (ICCFI 2017). Jeju Island, South Korea, 10-13 August.

Alqahtani, M. A., Al-Badi, A. H., \& Mayhew, P. J. (2012). The Enablers and Disablers of E-Commerce: Consumers' Perspectives. The Electronic Journal of Information Systems in Developing Countries, 54(1), 1-25.

Alrowwad, A., Obeidat, B.Y., \& Aqqad, N. (2017). The impact of transformational leadership on organizational performance via the mediating role of corporate social responsibility: A structural equation modeling approach. International Business Research, 10(1), 199-221. https://doi.org/10.5539/ibr.v10n1p199

Alshurideh, M., Masa'deh, R., \& Alkurdi, B. (2012). The Effect of Customer Satisfaction on Customer Retention in the Jordanian Mobile Market: An Empirical Investigation. European Journal of Economics, Finance and Administrative Sciences, 47, 69-78.

Altamony, H., Alshurideh, M., \& Obeidat, B. (2012). Information Systems for Competitive Advantage: Implementation of an Organizational Strategic Management Process. Proceedings of the 18th IBIMA Conference on Innovation and Sustainable Economic Competitive Advantage: From Regional Development to World Economic, Istanbul, Turkey, 9th-10th May.

Altamony, H., Al-Salti, Z., Gharaibeh, A., \& Elyas, T. (2016). The relationship between Change Management Strategy and Successful Enterprise Resource Planning (ERP) Implementations: A Theoretical Perspective. International Journal of Business Management and Economic Research, 7(4), 690-703.

Anwar, A.S. (2008). A Factor Analytic Investigation of the Construct of Market Orientation. International Journal of Management, 25(1), 186-197.

Bagozzi, R., \& Yi, Y. (1988). On the Evaluation of Structural Evaluation Models. Journal of the Academy of Marketing Science, 16(1), 74-94. https://doi.org/10.1007/BF02723327

Barney, J. (1991). Firm Resources and Sustained Competitive Advantage. Journal of Management, 17(1), 99-120.

Bisharat, H., Obeidat, B.Y., Alrowwad, A., Tarhini, A., \& Mukattash, I. (2017). The Effect of Human Resource Management Practices on Organizational Commitment in Chain Pharmacies in Jordan. International Journal of Business and Management, 12(1), 50-67. https://doi.org/10.5539/ijbm.v12n1p50

Brodie, R. J., Winklhofer, H., Coviello, N. E., \& Johnston, W. J. (2007). Is E-Marketing Coming of Age? An Examination of the Penetration of E-Marketing and Firm Performance. Journal of Interactive Marketing, 21(1), 2-20. https://doi.org/10.1002/dir.20071

Calantone, J., \& Mazanec, A. (1991). Marketing Management and Tourism. Annals of Tourism Research, 18(1), 101-119. https://doi.org/10.1016/0160-7383(91)90042-A

Claver-Cortés, E., Pereira-Moliner, J., Tarí, J.J., \& Molina-Azorín, J.F. (2008). TQM, Managerial Factors and Performance in the Spanish Hotel Industry. Industrial Management \& Data Systems, 108(2), 228-244.

Coviello, E., Milley, R., \& Marcolin, B. (2001). Understanding IT-Enabled Interactivity in Contemporary Marketing. Journal of Interactive Marketing, 18-33. https://doi.org/10.1002/dir.1020

Creswell, J. (2009). Research Design: Qualitative, Quantitative, and Mixed Methods Approaches (3rd ed.). Thousand Oaks: Sage Publications.

Dlodlo, N., \& Dhurup, M. (2010). Barriers to E-Marketing Adoption among Small and Medium Enterprises (SMEs) in the Vaal Triangle. Acta Commercii, 164-180. https://doi.org/10.4102/ac.v10i1.126

El-Gohary, H. (2012). Factors Affecting E-Marketing Adoption and Implementation in Tourism Firms: An Empirical investigation of Egyptian Small Tourism Organizations. Tourism Management, 1256-1269.

El-Masri, M., \& Tarhini, A. (2015). A Design Science Approach to Gamify Education: From Games to Platforms. Twenty-Third European Conference on Information Systems (ECIS), Münster, Germany. 26-29 May 2015.

El-Masri, M., \& Tarhini, A. (2017). Factors affecting the adoption of e-learning systems in Qatar and USA: Extending the Unified Theory of Acceptance and Use of Technology 2 (UTAUT2). Educational Technology Research and Development, 65(3), 743-763. https://doi.org/10.1007/s11423-016-9508-8

El-Masri, M., Orozco, J., Tarhini, A., \& Tarhini, T. (2015). The Impact of IS-Business Alignment Practices on Organizational Choice of IS-Business Alignment Strategies. The 19th Pacific Asia Conference on Information Systems (PACIS 2015), Paper 215, Singapore, 6-9 July 2015. 
Elyas, T. \& Picard, P. (2012). Teaching and Moral Tradition in Saudi Arabia: A Paradigm of Struggle or Pathway towards Globalization?. Procedia - Social and Behavioral Sciences, 41, 1083-1086.

Fedai, L., Daglı, G., Altınay, Z., \& Altınay, F. (2017). The examination of occupational burnout and job satisfaction of the physical education teachers. International Journal of Economic Perspectives, 11(1), 12-26.

Fronell, C., \& Larcker, D. (1981). Evaluating Structural Equation Models with Unobservable Variables and Measurement Error. Journal of Marketing Research, 18, 39-50. https://doi.org/10.2307/3151312

Grandzol, J.R., \& Gershon, M. (1998). A Survey Instrument for Standardizing TQM Modeling Research. International Journal of Quality Science, 80-105. https://doi.org/10.1108/13598539810203887

Hair, J., Black, W., Babin, B., Anderson, R., \& Tatham, R. (2006). Multivariate Data Analysis (6th ed.). New Jersey: Prentice-Hall.

Hair, J., Black, W., Babin, B., Anderson, R., \& Tatham, R. (2010). Multivariate Data Analysis (7th ed.). New Jersey: Prentice-Hall.

Hajir, J., Obeidat, B., \& Al-dalahmeh, M. (2015). The Role of Knowledge Management Infrastructure in Enhancing Innovation at Mobile Telecommunication Companies in Jordan. European Journal of Social Sciences, 50(3), 313-330.

Hamoud, M., Akour, M. A., \& Al-Salti, Z. (2016). Developing the Main Knowledge Management Process via Social Media in the IT Organisations: A Conceptual Perspective. International Journal of Business Administration, 7(5), 49-64.

Hassouna, M., Elyas, T., \& Abou Trab, M. S. (2015). Customer Churn in Mobile Markets: A Comparison of Techniques. International Business Research, 8(6), 224-237. https://doi.org/10.5539/ibr.v8n6p224

Hussian, A., Elyas, T., \& Nasseef, O. (2013). Research Paradigms: A Slippery Slope for Fresh Researchers. Life Science Journal, 10(4), 2374-2381.

Hunaiti, Z., Mansour, M., \& Al-Nawafleh. (2009). Electronic Commerce Adoption Barriers in Small and Medium-Sized Enterprises (SMEs) in Developing Countries: The Case of Libya. IBIMA Business Review, 2(5), 37-45.

Jordanian Ministry of Tourism and Antiquities. Retrieved from http://www.mota.gov.jo

Kanaan, R., \& Gharibeh, A. (2013). The Impact of Knowledge Sharing Enablers on Knowledge Sharing Capability: An Empirical Study on Jordanian Telecommunication Firms. European Scientific Journal, 9(22), 237-258.

Kateb, M., Swies, R., Obeidat, B., \& Maqableh, M. (2015). An Investigation on the Critical Factors of Information System Implementation in Jordanian Information Technology Companies. European Journal of Business and Management, 7(36), 11-28.

Kerin, R.A., Hartley, S.W., Berkowitz, E.N., \& Rudelius, W. (2006). Marketing (8th ed.). McGraw-Hill, Boston.

Kline, R. (2010). Principles and Practice of Structural Equation Modeling. The Guilford Press.

Kohli, K., \& Jaworski, J. (1990, April). Market Orientation: The Construct, Research Propositions, and Managerial Implications. Journal of Marketing, 54, 1-18. https://doi.org/10.2307/1251866

Krejcie, R., \& Morgan, D. (1970). Determining Sample Size for Research Activities. Educational and Psychological Measurement, 30, 607-610. https://doi.org/10.1177/001316447003000308

Lai, K.H. (2003). Market Orientation in Quality-Oriented Organizations and its Impact on their Performance. International Journal of Production Economics, 84(1), 17-34. https://doi.org/10.1016/S0925-5273(02)00382-1

Lamb, W., Hair, F., \& McDaniel, C. (2005). Marketing (8th ed.). ThomsonSouth-Western Inc., Mason, OH.

Langer, M. (1997). Service Quality in Tourism: Measurement Methods and Empirical Analysis. Peter Lang, Frankfurt.

Lazari, G., \& Kanellopoulos, D.N. (2007). Total Quality Management in Hotel Restaurants: A Case Study in Greece. Journal of engineering and applied sciences, 2(3), 564-571.

Lončarić, D., \& Radetić, N. (2015). The Implementation of E-Marketing in the Hotel Industry: The Case of Istria County. Zbornik Veleučilišta u Rijeci, 3(1), 15-26.

Maqableh, M., \& Karajeh, H. (2014a). Job Scheduling for Cloud Computing Using Neural Networks. 
Communications and Network, 6(3), 191. https://doi.org/10.4236/cn.2014.63021

Maqableh, M., \& Karajeh, H. (2014b). A Theoretical Perspective on the Relationship between Leadership Development, Knowledge Management Capability, and Firm Performance. Asian Social Science, 10(6), 128.

Mahadeen, B., Al-Dmour, R., \& Obeidat, B. Y. (2016). Examining the effect of the Organization's Internal Control System on Organizational Effectiveness: A Jordanian empirical study. International Journal of Business Administration, 7(6), 22-41. https://doi.org/10.5430/ijba.v7n6p22

Masa'deh, R. (2013). The Impact of Information Technology Infrastructure Flexibility on Firm Performance: An Empirical Study of Jordanian Public Shareholding Firms. Jordan Journal of Business Administration, $204-224$.

Masa'deh, R., \& Kuk, G. (2009). Antecedents and Intermediaries between Strategic Alignment and Firm Performance. Conference of the Academy of Management Annual Meeting (AOM), Illinois, Chicago, USA.

Masa'deh, R., Gharaibeh, A., Maqableh, M., \& Karajeh, H. (2013a). An Empirical Study of Antecedents and Outcomes of Knowledge Sharing Capability in Jordanian Telecommunication Firms: A Structural Equation Modeling Approach. Life Science Journal, 10(4), 2284-2296.

Masa'deh, R., Hunaiti, Z., \& Bani Yaseen, A. (2008). An Integrative Model Linking IT-Business Strategic Alignment and Firm Performance: The Mediating Role of Pursuing Innovation and Knowledge Management Strategies. Communications of the International Business Information Management Association (IBIMA) Journal, 2(24), 180-187.

Masa'deh, R., Shannak, R., \& Maqableh, M. (2013b). A Structural Equation Modeling Approach for Determining Antecedents and Outcomes of Students' Attitude toward Mobile Commerce Adoption. Life Science Journal, 10(4), 2321-2333.

Masa'deh, R., Tayeh, M., Al-Jarrah, I., \& Tarhini, A. (2015c). Accounting vs. Market-based Measures of Firm Performance Related to Information Technology Investments. International Review of Social Sciences and Humanities, 129-145.

Masa'deh, R. (2012). The Impact of Management Information Systems (MIS) on Quality Assurance (QA): A Case Study in Jordan. International Journal of Information, Business, and Management, 93-110.

Masa'deh, R., \& Shannak, R. (2012). Intermediary Effects of Knowledge Management Strategy and Learning Orientation on Strategic Alignment and Firm Performance. Research Journal of International Studies, 112-128.

Masa'deh, R., Gharaibeh, A., Tarhini, A., \& Obeidat, O. (2015a). Knowledge Sharing Capability: A Literature Review. In Fourth Scientific \& Research Conference on New Trends in Business, Management and Social Sciences, Istanbul, Turkey, 19-20 September 2015 (pp. 1-16). https://doi.org/10.2139/ssrn.2696924

Masa'deh, R., Obeidat, B., \& Tarhini, A. (2016). A Jordanian Empirical Study of the Associations among Transformational Leadership, Transactional Leadership, Knowledge Sharing, Job Performance, and Firm Performance: A Structural Equation Modelling Approach. Journal of Management Development, 35(5), 681-705. https://doi.org/10.1108/JMD-09-2015-0134

Masa'deh, R., Obeidat, B., Al-Dmour, R., \& Tarhini, A. (2015b). Knowledge Management Strategies as Intermediary Variables between IT-Business Strategic Alignment and Firm Performance. European Scientific Journal, 11(7), 344-368.

Masa'deh, R., Shannak, R., Maqableh, M., \& Tarhini, A. (2017). The Impact of Knowledge Management on Job Performance in Higher Education: The Case of the University of Jordan. Journal of Enterprise Information Management, 30(2), 244-262. https://doi.org/10.1108/JEIM-09-2015-0087

Mehmet. D., \& Lenny Koh, S. (2006). TQM and Market Orientation's Impact on SMEs' Performance. Industrial Management and Data Systems, 1206-1228.

Mohr-Jackson, I. (1991). Broadening the Market Orientation: An Added Focus on Internal Customers. Human Resource Management, 455-467. https://doi.org/10.1002/hrm.3930300403

Montes, F., Jover, A., \& Ferna'ndez, L. (2003). Factors Affecting The Relationship Between Total Quality Management and Organizational Performance. International Journal of Quality \& Reliability Management, 189-209. https://doi.org/10.1108/02656710310456617

Narver, D., \& Slater, F. (1990). The Effect of a Market Orientation on Business Profitability. Journal of Marketing, 20-35. https://doi.org/10.2307/1251757 
Nassar, B., \& Arzoky, M. (2015). An Empirical Analysis of the Seasonal Patterns in Aggregate Directors' Trades. International Journal of Economics and Finance, 7(9), 59-84. https://doi.org/10.5539/ijef.v7n9p59

Obeidat, B. Y., Hashem, L., Alansari, I, \& Al-Salti, Z. (2016). The Effect of Knowledge Management Uses on Total Quality Management Practices: A Theoretical Perspective. Journal of Management and Strategy, 7(4), 18-29.

Obeidat, B., Al-Suradi, M., \& Tarhini, A. (2016). The Impact of Knowledge Management on Innovation: An Empirical Study on Jordanian Consultancy Firms. Management Research Review, 39(10), 1214-1238.

Obeidat, B., El-Rimawi, S., Maqableh, M., \& Al-Jarrah, I. (2013). Evaluating the Profitability of the Islamic Banks in Jordan. European Journal of Economics, Finance and Administrative Sciences, 56, 27-36.

Obeidat, B., Sweis, R., Zyod, D., \& Alshurideh, M. (2012). The Effect of Perceived Service Quality on Customer Loyalty in Internet Service Providers in Jordan. Journal of Management Research, 4(4), 224-242.

Obeidat, B.Y., Al-Sarayrah, S., Al-Salti, Z., \& Sweis, R. (2016). Cultural Influence on Strategic Human Resource Management Practices: A Jordanian case study. International Business Research, 9(10), 94-114.

Obeidat, B.Y., Tarhini, A., \& Aqqad, N. (2017). The impact of intellectual capital on innovation via the mediating role of knowledge management: A structural equation modeling approach. International Journal of Knowledge Management Studies, 8(2), 15-33.

Orozco, J., Tarhini, A., Masa'deh, R., \& Tarhini, T. (2015). A framework of IS/business alignment management practices to improve the design of IT Governance architectures. International Journal of Business and Management, 10(4), 1-12. https://doi.org/10.5539/ijbm.v10n4p1

Pallant, J. (2005). SPSS Survival Manual: A Step Guide to Data Analysis Using SPSS for Windows Version 12. Chicago, Illinois: Open University Press.

Peštek, A., \& Čičić, M. (2010). Practical Aspects of E-Marketing Application in Tourism Development in Bosnia and Herzegovina, Proceedings of International Conference ICES - Economic Development Perspectives of SEE Region in Global Recession Context. Sarajevo, October.

Piercy, F. (1998). Marketing Implementation: The Implications of Marketing Paradigm Weakness for the Strategy Execution Process. Journal of the Academy of Marketing Science, 26(3), 222-236.

Powell, C. (1995). Total Quality Management as Competitive Advantage: A Review and Empirical Study. Strategic Management Journal, 16(1), 15-37. https://doi.org/10.1002/smj.4250160105

Raju, P, \& Lonial, S. (2002). The Impact of Service Quality and Marketing on Financial Performance in the Hospital Industry: An Empirical Examination. Journal of Retailing and Consumer Services, 335-348.

Ruekert, R.W. (1992). Developing a Market Orientation: An Organizational Strategy Perspective. International Journal of Research in Marketing, 225-245. https://doi.org/10.1016/0167-8116(92)90019-H

Santos-Vijande, M.L., \& Álvarez-González, L.I. (2009). TQM's Contribution to Marketing Implementation and Firm's Competitiveness. Total Quality Management, 171-196. https://doi.org/10.1080/14783360802622953

Sekaran, U., \& Bougie, R. (2013). Research Methods for Business: A Skill-Building Approach (6th ed.). New York: Wiley.

Shannak, R., \& Akour, M. (2012). Knowledge Management Strategy Building: Literature Review. European Scientific Journal, 8(15), 143-168.

Shannak, R., Al-Zu'bi, Z., Obeidat, B., Alshurideh, M., \& Altamony, H. (2012a). A Theoretical Perspective on the Relationship between Knowledge Management Systems, Customer Knowledge Management, and Firm Competitive Advantage. European Journal of Social Sciences, 32(4), 520-532.

Shannak, R., Obeidat, B., \& Almajali, D. (2010). Information Technology Investments: A Literature Review. Proceedings of the 14th IBIMA Conference on Global Business Transformation through Innovation and Knowledge Management: An Academic Perspective, Istanbul-Turkey, 23rd-24th June, pp.1356-1368.

Shannak, R., Obeidat, B., \& Masa'deh, R. (2012b). Culture and the Implementation Process of Strategic Decisions in Jordan. Journal of Management Research, 4(4), 257-281. https://doi.org/10.5296/jmr.v4i4.2160

Shuai, J. J., \& Wu, W. W. (2011). Evaluating the Influence of E-marketing on Hotel Performance by DEA and Grey Entropy. Expert Systems with Applications, 8763-8769. https://doi.org/10.1016/j.eswa.2011.01.086

Sin, L., Tse, A., Heung, V., \& Yim, F. (2005). An Analysis of the Relationship between Market Orientation and 
Business Performance in the Hotel industry. Hospitality Management, 24(6), 555-577.

Sittimalakorn, W., \& Hart, S. (2004). Market Orientation Versus Quality Orientation: Sources of Superior Business Performance. Journal of Strategic Marketing, 243-253. https://doi.org/10.1080/0965254042000308066

Sureshchandar, G.S., Rajendran, C., \& Anantharaman, R.N. (2001). A Conceptual Model for Total Quality Management in Service Organizations. Total Quality Management, 343-363.

Tarhini, A., Al-Badi, A., Almajali, M., \& Alrabayaah, S. H. (2017). Factors influencing employees' Intention to use Cloud Computing. Journal of Management \& Strategy, 8(2), 47-62. https://doi.org/10.5430/jms.v8n2p47

Tarhini, A., Elyas, T., Akour, M. A., \& Al-Salti, Z. (2016). Technology, Demographic Characteristics and E-Learning Acceptance: A Conceptual Model Based on Extended Technology Acceptance Model. Higher Education Studies, 6(3), 72-89. https://doi.org/10.5539/hes.v6n3p72

Tarhini, A., El-Masri, M., Ali, M., \& Serrano, A. (2016). Extending the UTAUT model to understand the customers' acceptance and use of internet banking in Lebanon: A structural equation modeling approach. Information Technology and People, 29(4), 830-849. https://doi.org/10.1108/ITP-02-2014-0034

Tarhini, A., Arachchilage, N., \& Abbasi, M. (2015). A Critical Review of Theories and Models of Technology Adoption and Acceptance in Information System Research. International Journal of Technology Diffusion, 6(4), 58-77. https://doi.org/10.4018/IJTD.2015100104

Tarhini, A., Mgbemena, C., AbouTrab, M.S., \& Masa'deh, R. (2015). User Adoption of Online Banking in Nigeria: A Qualitative study. Journal of Internet Banking and Commerce, 20(3), 1-8.

Tarhini, A., Mohammed, A., \& Maqableh, M. (2016). Modeling Factors Affecting Student's Usage Behaviour of E-Learning Systems in Lebanon. International Journal of Business and Management, 11(2), 299-314.

Tena, A.B.E., Llusar, J.C.B., \& Puig, V.R. (2001). Measuring the Relationship between Total Quality Management and Sustainable Competitive Advantage: A Resource-based View. Total Quality Management, 12(7\&8), 932-938. https://doi.org/10.1080/09544120100000018

Tsiaotso, R, H., \& Flahibl, M. (2011). Understanding the Effects of Market Orientation and E-Marketing on Service Performance. Marketing Intelligence \& Planning, 141-155. https://doi.org/10.1108/02634501111117593

Van Zyl, H.J.C., \& Mathur-Helm, B. (2007). Exploring a Conceptual Model, based on the Combined Effects of Entrepreneurial Leadership, Market Orientation and Relationship Marketing Orientation on South Africa's Small Tourism Business Performance. South Africa Journal of Business Management, 38(2), 17-24.

Vratskikh, I., Al-Lozi, M., \& Maqableh, M. (2016). The Impact of Emotional Intelligence on Job Performance via the Mediating Role of Job Satisfaction. International Journal of Business and Management, 69-91.

Wang, C.H., \& Chen S.C. (2011). The Effect of the Link Total Quality Management and Market Orientation on Hotel performance. International Conference on Business and Economics Research.

Wang, C-H., Chen, K-Y., \& Chen, S-C. (2012). Total Quality Management, Market Orientation and Hotel Performance: The Moderating Effects of External Environmental Factors. International Journal of Hospitality Management, 31(2012), 119-129. https://doi.org/10.1016/j.ijhm.2011.03.013

Wang, E.T.G., \& Wei, H.L. (2005). The Importance of Market Orientation, Learning Orientation, and Quality Orientation Capabilities in TQM: An Example from Taiwanese Software Industry. Total Quality Management \& Business Excellence, 16(10), 1161-1177. https://doi.org/10.1080/14783360500236270

Wu, F., Mahajan, V., \& Balsubramanian, S. (2003). An Analysis of E-Business Adoption and its Impact on Business Performance. Journal of the Academy of Marketing Science, 425-447. https://doi.org/10.1177/0092070303255379

Yam, R.C.M., Tam, A.Y.K., Tang, E.P.Y., \& Mok, C.K. (2005). TQM: A Change Management Model on Market Orientation. Total Quality Management \& Business Excellence, 16(4), 439-461. https://doi.org/10.1080/14783360500078375

Youssef, M.A., Boyd, J., \& Williams, E. (1996). The Impact of Total Quality Management on Firms' Responsiveness: An Empirical Analysis. Total Quality Management, 7(1), 127-144. https://doi.org/10.1080/09544129650035098

Zhou, K.Z., Yim, CK., \& Tse, DK. (2005). The Effects of Strategic Orientations in Technology and Market-based Breakthrough Innovation. Journal of Marketing, 42-60. https://doi.org/10.1509/jmkg.69.2.42.60756 